\title{
Study on Holding Time Influence on Heat Treatments Applied to Modified Cast Irons
}

\author{
Maria STOICANESCU \\ Transilvania University of Brasov, Romania, stoican.m@unitbv.ro
}

\begin{abstract}
The purpose of this paper is studying the possibility of shortening the time of graphitization by combining two procedures, i.e. modification and malleableizing annealing. Thus, graphitization tests were performed in two stages on hypoeutectic cast iron. A quantity of modifier was introduced in the liquid cast iron at the beginning. After cooling and solidification, a graphitization process start was detected, i.e. small and compact graphite inclusions appeared on the white cast iron. Afterwards, a $900{ }^{\circ} \mathrm{C}$ annealing was applied, with holding times of $1-4 \mathrm{~h}$. Following this treatment, there was detected an increase in the size of primary graphite separations, concomitantly with the partial development of the second stage of graphitization. Through this succession of metallurgical operations, the treatment time was reduced from several tens of hours to about 2 hours.
\end{abstract}

Keywords

cast iron, heat treatment, metallurgical operations

\section{Introduction}

Graphite cast irons are widely spread in industrial practice being the metal alloy indispensable for the production of numerous products of industrial and economic interest. The most widely spread and the cheapest graphite cast iron is grey cast iron, which features numerous qualities that make it so widespread. A major shortcoming of this Fe-C alloy is the brittleness, bending and traction resistance), making it not appropriate for certain parts $[2,5,6]$. The brittleness decrease while preserving the other qualities is achieved by compacting the graphite shape. This transformation is achieved by malleableizing [4].

Malleableizing is difficult and requires a lot of time. The malleableizing time can be shortened by adding internal stresses that can become graphitization centres by quenching. However, in its turn, creates a risk cracking and deformation $[7,8]$. In this context, the paper describes the attempt to replace the pre-malleableizing quenching with a liquid cast iron modification.

The cast irons modification is aimed at increasing the compactness of graphite separations while increasing the number of eutectic cells. This is achieved by major modifications to the structure in the cast iron liquid state. The efficiency of these modifications depends to a large extent on the structure of the liquid cast iron at the time of adding modifiers and on the temperature at which this operation is performed.

The modifications occurring in the structure of the liquid cast iron upon the addition of modifiers depend on their graphitizing or anti-graphitizing influence $[1,3,4]$. When adding graphitizing modifiers to liquid cast iron, there occurs a large number of suspended chemical combinations (solid particles), which may act as graphitization nuclei.

Therefore the graphitizing modification intensifies the colloidal solution character of liquid cast irons. The efficiency of graphitizing modifications depends on the possibility of these inclusions to influence the nucleation of graphite during the eutectic crystallization, in order to increase the number of graphite separations.

In order to be able to exert their influence, the inclusions must be present and also active during the crystallization of the cast iron. From this point of view, the cast iron temperature when the modifier is added is of outmost importance. This is established so that the chemical combination obtained from the modification is thermodynamically stable $[1,3,4]$.

The effect of the graphitizing modifiers is assessed according to the following criteria: 
- decrease in the whitening tendency of modified cast irons;

- decrease in the undercooling degree upon the eutectic crystallization;

- eutectic cell size or number variation;

- modification effect duration.

The more active non-metallic inclusions obtained during the modification, the more graphite separations. For the same number of inclusions, the number of eutectic cells increases with the undercooling of eutectic crystallization [5].

The structure finishing modification is aimed at increasing the number of graphite separations and eutectic cells and to uniformize the structure. Graphite is influenced more in terms of number of separations and manner of distribution in the structure, and less with regard to its compactness. Therefore, this type of modification corresponds to the specific graphitizing modification of grey cast irons.

The nodulizing modification is aimed at increasing the graphite compactness, being the technological method for the production of compacted graphite cast irons (Fgv, Fgn). Nodulizing modifiers are sometimes also used to treat malleable cast iron to improve the graphite shape, while reducing the malleableizing treatment.

\section{Work Method}

The aim of this paper is to study the holding time influence on the malleableizing treatment applied to modified cast irons.

A cast iron with the chemical composition was used for this study: $\mathrm{C}=3.49 \%$; $\mathrm{Si}=1.89 \%$; $\mathrm{Mn}=0.62 \% ; \mathrm{P}=0.065 \% ; \mathrm{S}=0.035 \% ; \mathrm{Ni}=0.184 \% ; \mathrm{Cr}=0.289 \% ; \mathrm{Al}=0.0144 \% ; \mathrm{Mo}=0.041 \%$; $\mathrm{Cu}=0.19 \% ; \mathrm{V}=0.01 \% ; \mathrm{Ti}=0.0123 \% ; \mathrm{Mg}=0.0019 \% ; \mathrm{Fe}=93.83 \% ; \mathrm{Pb}=0.003 \% ; \mathrm{Zn}=0.0010 \%$; $\mathrm{Ceq}=4.14 \%$; $\mathrm{Sc}=0.957 \%$.

The chemical composition of malleable cast irons is closely related to their type. Regardless of the type of malleable cast iron, its casting structure must not contain graphite, which cannot be modified by heat treatments, and thus it should have a white cast iron structure.

The melting temperature was $1450{ }^{\circ} \mathrm{C}$, and the overheating was performed at $1550{ }^{\circ} \mathrm{C}$, followed by the modification.

Overheating greatly influences the structure of the cast iron in liquid state and thereby the crystallization conditions upon cooling.

Liquid cast iron has a complex structure, depending on the nature of the metallic materials and the smelting conditions, the chemical composition and the heat regime.

For cast iron whose composition has been shown above, the modification was performed using NODULIN.

Overheating can be used to improve the quality of cast irons, but its action is effectively harnessed only when it is followed by obtaining nuclei of controlled size, number and distribution, respectively when modifying the cast iron.

From the cast iron thus prepared, two samples were taken before modification and two samples after modification. From each sample, smaller samples were taken and they underwent a heat treatment at $900{ }^{\circ} \mathrm{C}$ for holding times between 1 to 4 hours; the samples were removed from the furnace one by one every half an hour, with the first one after one hour, the second after an hour and a half, the third after two hours, etc. The samples were cooled in air. The samples were held at $900{ }^{\circ} \mathrm{C}$ because they were very small and did not require a higher temperature.

In the case of malleable cast irons, the heat treatment applied is malleablizing annealing, intended to decompose (eutectic) cementite from the structure and to obtain graphite inclusions, a characteristic shape of these cast irons. This cast iron is heated in the austenitic range at about $850 \ldots 950{ }^{\circ} \mathrm{C}$, held at the same temperature for a certain time and then cooled at a certain speed.

The decomposition of cementite during the first stage of graphitization can be described by the expression:

$$
d M=\beta \cdot M \cdot d t
$$

where: 
$d M$ is the mass of decomposed cementite during $d t$;

$M$ - the total mass of cementite existing at all times;

$\beta$ - proportionality coefficient dependent on the composition of the cast iron and the temperature.

The number of graphite separations occurring during malleableizing is largely influenced by the cooling rate of the casting upon solidification.

The heat treatment performed according to the cyclogram presented in Figure 1.

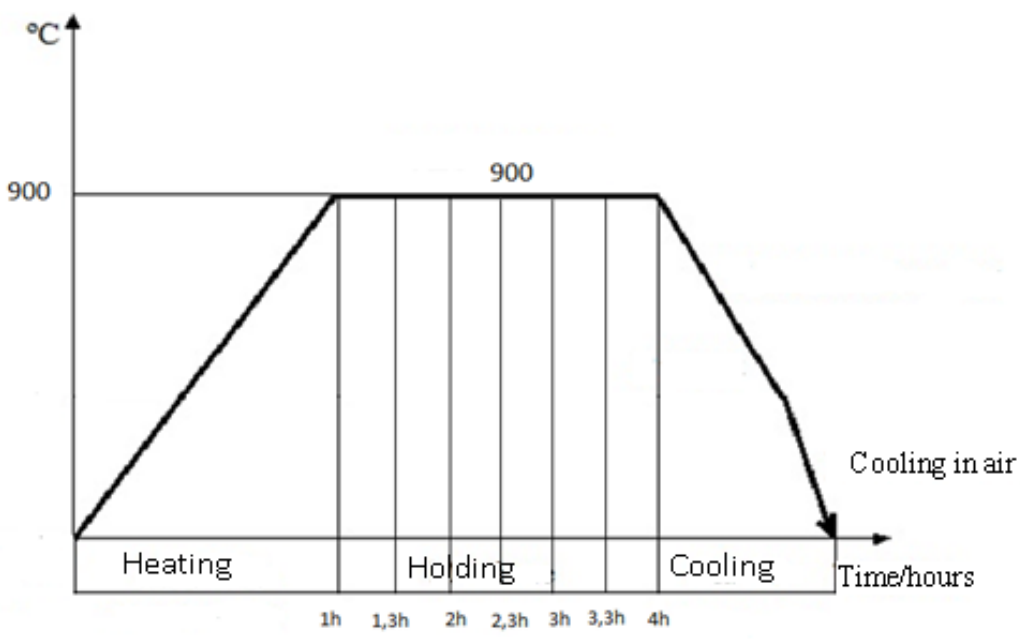

Fig. 1. Treatment cyclogram

The samples thus obtained were prepared for metallographic analysis (Figure 2). It followed the Nital etching of the samples in order to observe the structure as accurately as possible.

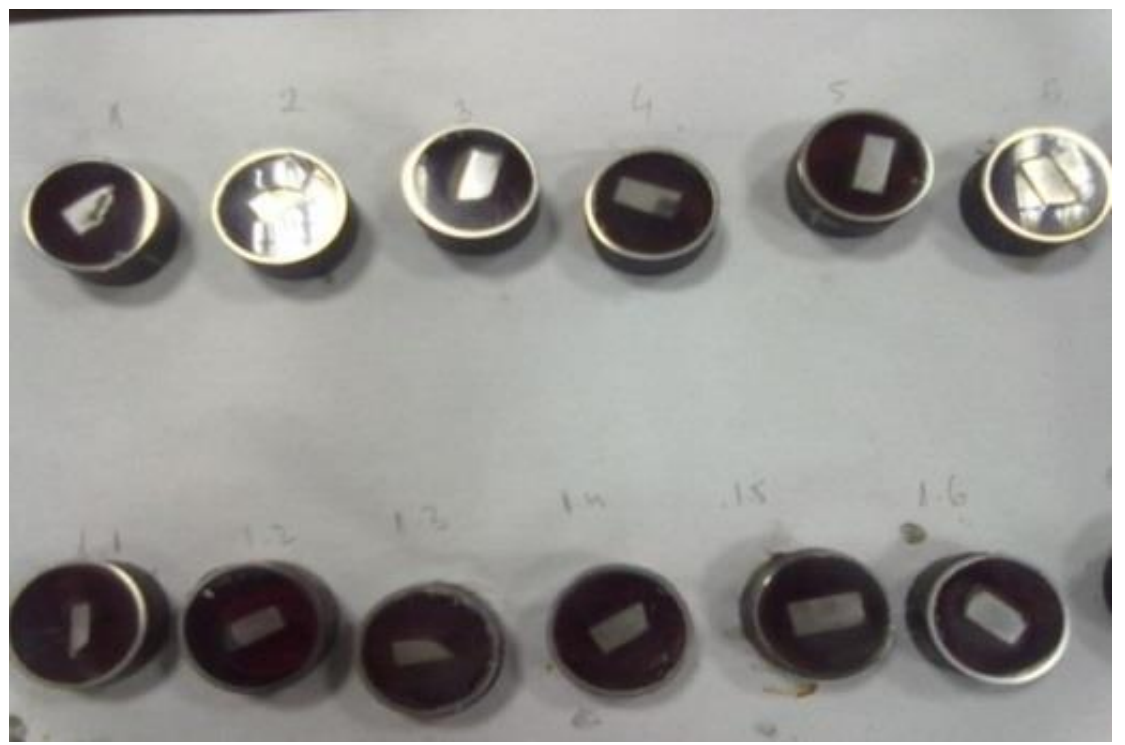

Fig. 2. The samples on which the metallographic analysis was performed

\section{Results}

The sample structure analysis shows that the cementite in the structure decomposes the longer the holding time is, resulting in the occurrence of graphite. The parameters of the malleableizing treatment (temperature, time) determine the number of graphite separations occurring in the structure. The number of graphite separations occurring during malleableizing is largely influenced by the cooling rate of the casting upon solidification. The higher it is, the greater the number of graphite separations.

In Figures 3 - 9 is presented the structure for unmodificate cast iron samples after they have been subjected at heat treatment in different conditions. 
RECENT, Vol. 21, no. 1(60), 2020

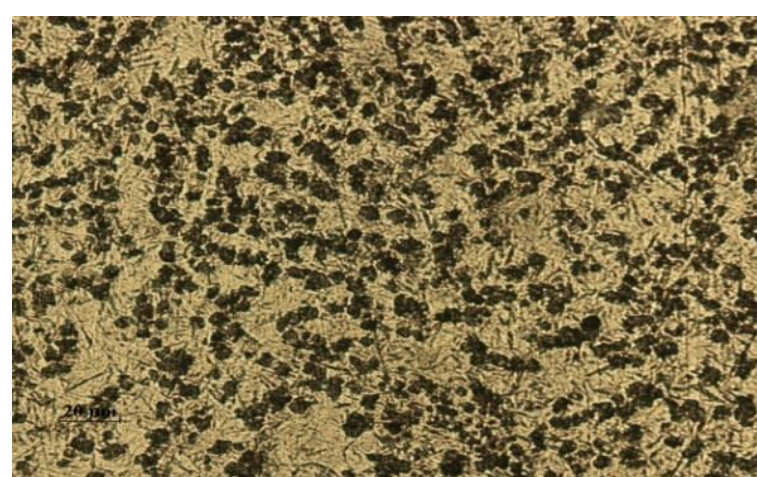

Fig. 3. Sample 1 structure before modification $1 \mathrm{~h}$, attack Nital, X50

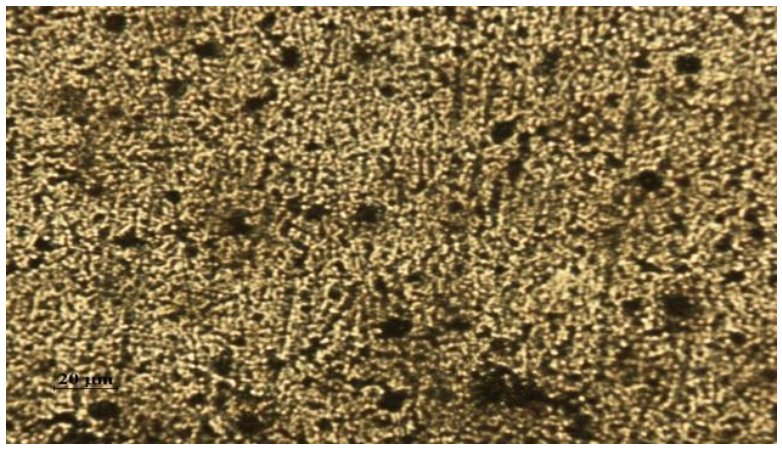

Fig. 5. Sample 3 structure before modification $2 \mathrm{~h}$, attack Nital, X50

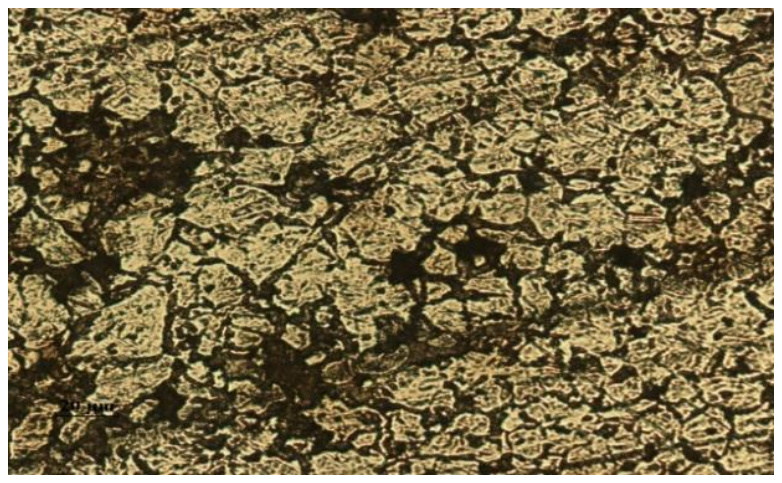

Fig. 7. Sample 5 structure before modification $3 \mathrm{~h}$, attack Nital, X50

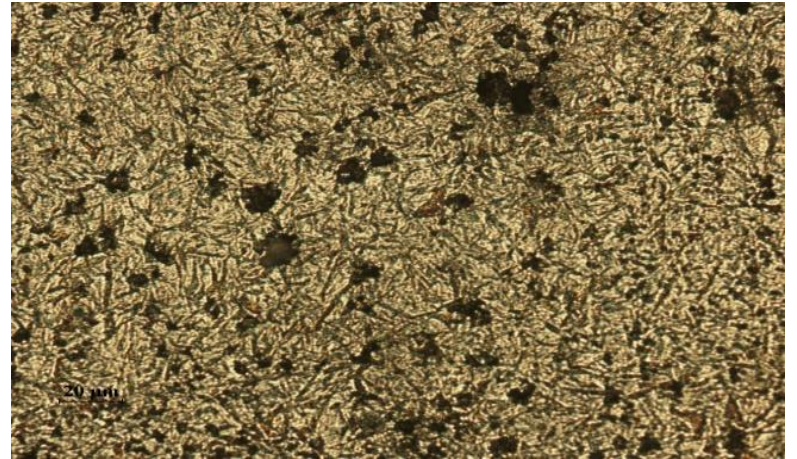

Fig. 4. Sample 2 structure before modification $1.3 \mathrm{~h}$, attack Nital, X50

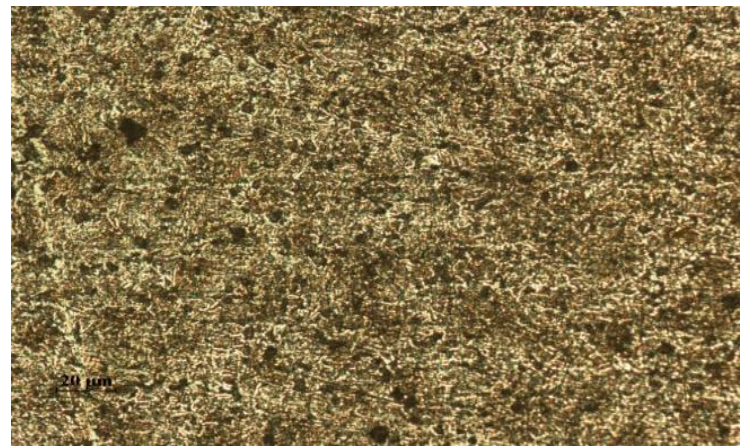

Fig. 6. Sample 4 structure before modification $2.3 \mathrm{~h}$, attack Nital, X50

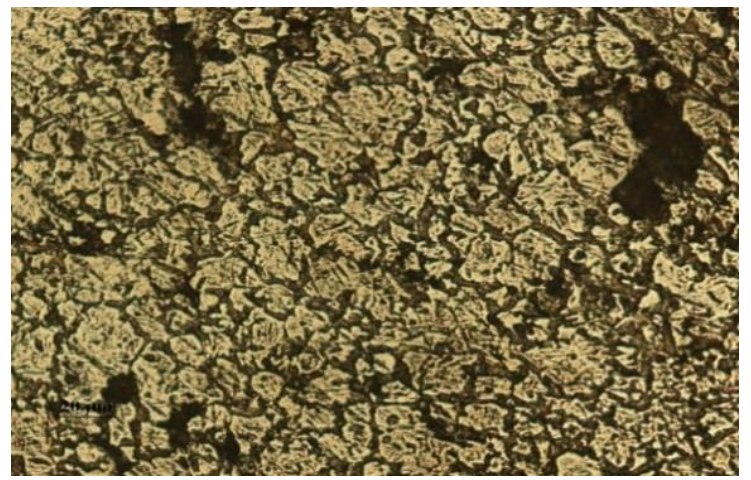

Fig. 8. Sample 6 structure before modification $3.3 \mathrm{~h}$, attack Nital, X50

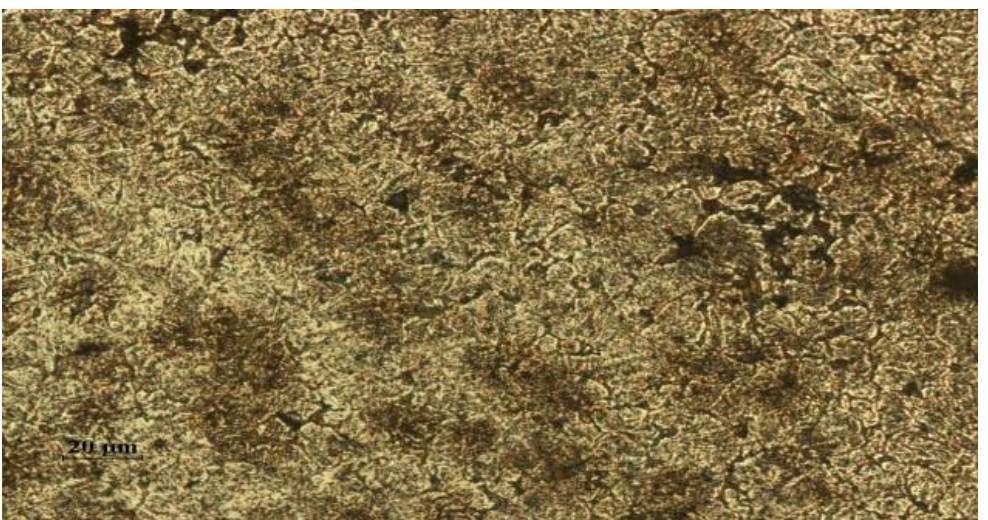

Fig. 9. Sample 7 structure before modification $4 \mathrm{~h}$, attack Nital, X50 
RECENT, Vol. 21, no. 1(60), 2020

In Figures 10 - 16 is presented the structure for modified cast iron samples after they have been subjected to heat treatment in different conditions.

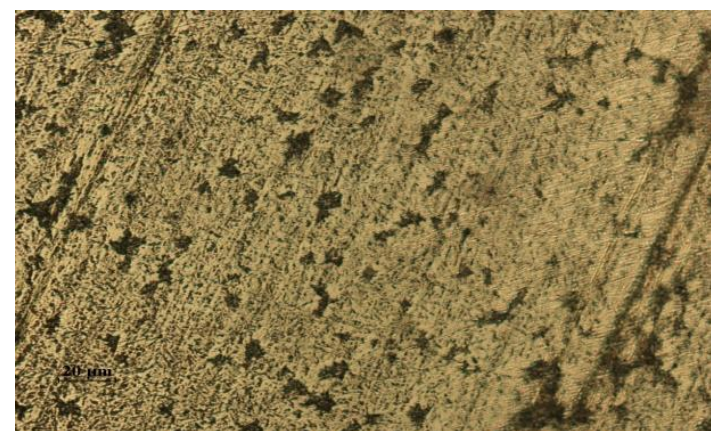

Fig. 10. Sample 1 structure after modification $1 \mathrm{~h}$, attack Nital, X50

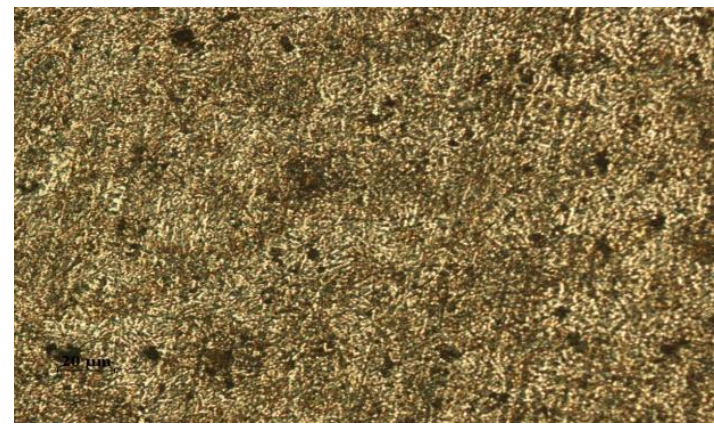

Fig. 12. Sample 3 structure after modification $2 \mathrm{~h}$, attack Nital, X50

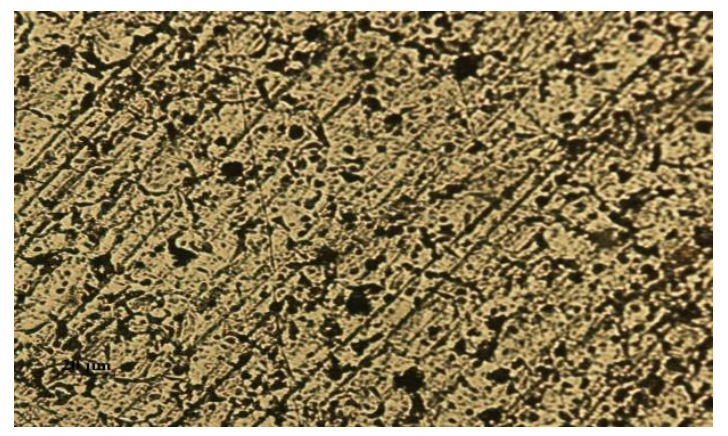

Fig. 14. Sample 5 structure after modification $3 \mathrm{~h}$, attack Nital, X50

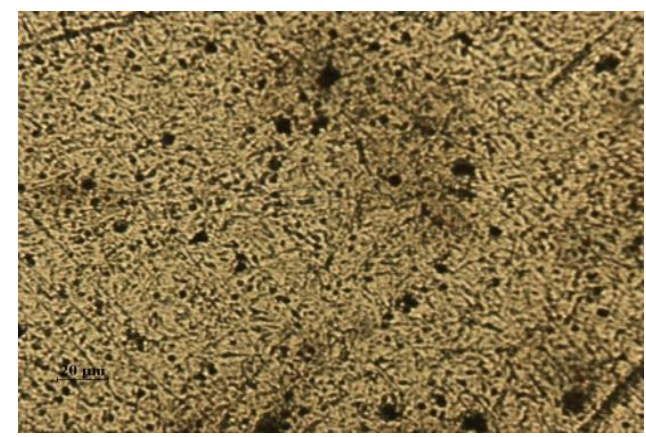

Fig. 11. Sample 2 structure after modification $1.3 \mathrm{~h}$, attack Nital, X50

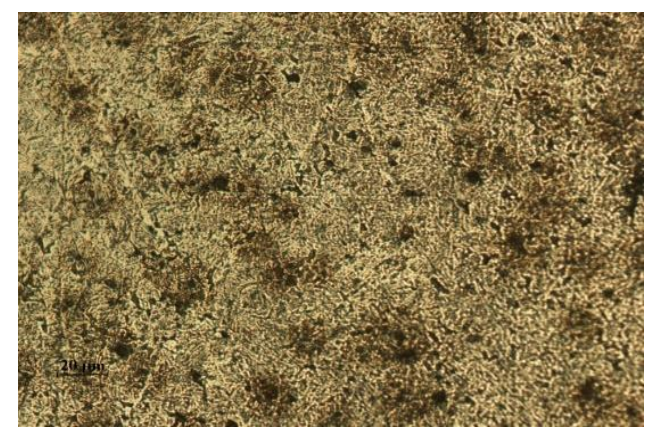

Fig. 13. Sample 4 structure after modification $2.3 \mathrm{~h}$, attack Nital, X50

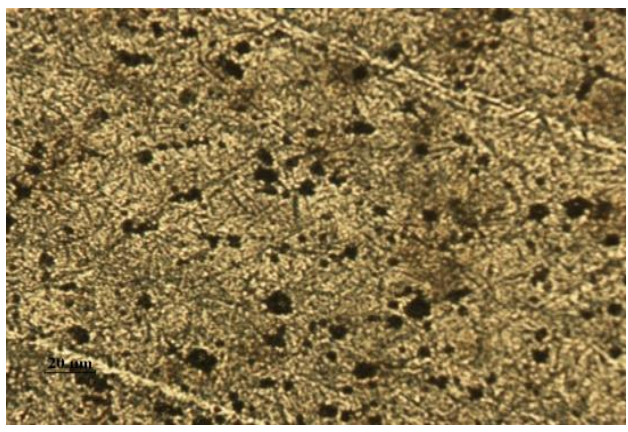

Fig. 15. Sample 6 structure after modification $3.3 \mathrm{~h}$, attack Nital, X50

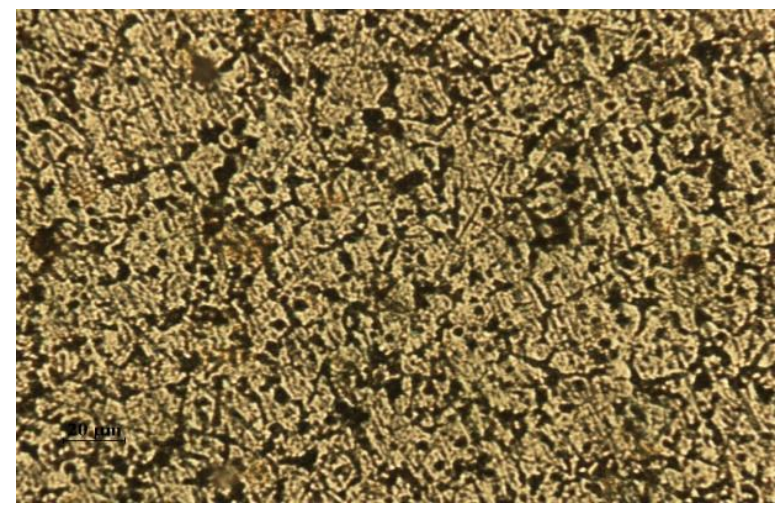

Fig. 16. Sample 7 structure after modification 4 h, attack Nital, X50 
There can be observed the white cast iron structure of Sample1 before the modification, a very fine structure consisting of ledeburite + pearlite (Figure 17). The sample 1 structure after the modification is still of white cast iron, but graphite occurred (Figure 18).

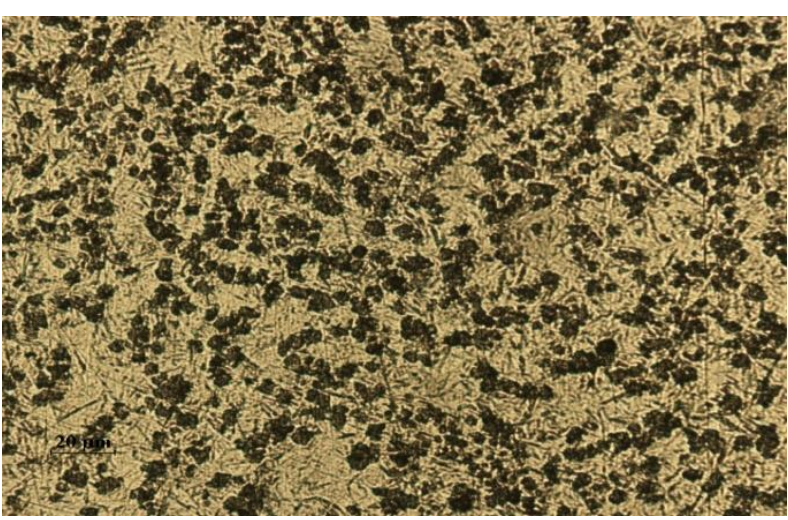

Fig. 17. Sample1 before the modification, attack Nital, X50

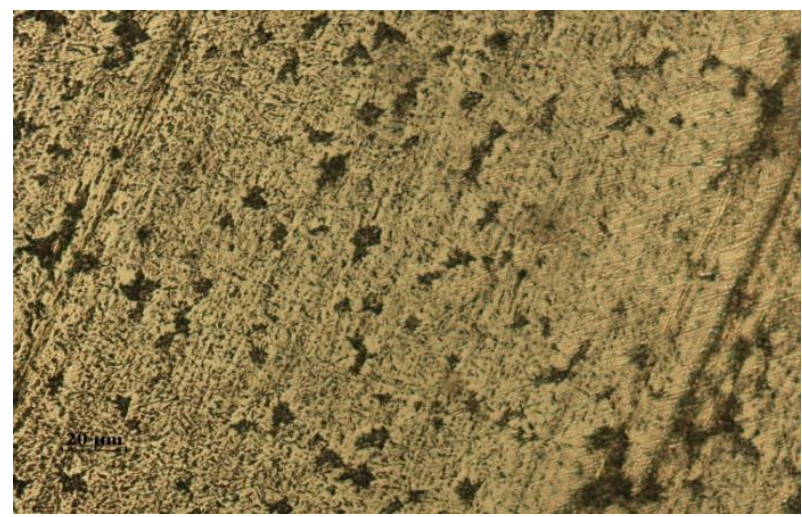

Fig. 18. Sample1 after the modification, attack Nital, X50

The structures could be viewed and we could study them at a magnification x 50 with the help of a Nikon image analyser.

The mechanical stresses applied to the studied material are presented in Table 1.

Table 1. Traction test

\begin{tabular}{|c|c|c|}
\hline Test type & Required results & Obtained results \\
\hline $\mathrm{R}_{\mathrm{ch}}$ & Min. $250 \mathrm{~N} / \mathrm{mm}^{2}$ & $274 \mathrm{~N} / \mathrm{mm}^{2}$ \\
\hline $\mathrm{R}_{\mathrm{m}}$ & Min. $400 \mathrm{~N} / \mathrm{mm}^{2}$ & $561 \mathrm{~N} / \mathrm{mm}^{2}$ \\
\hline $\mathrm{A}_{5}$ & Min. $12 \%$ & $12.2 \%$ \\
\hline
\end{tabular}

\section{Conclusions}

The theoretical studies and the experimental tests carried out for this paper yielded the conclusions below.

The research carried out on the samples show that the cementite decomposes the longer the holding time is, resulting in the occurrence of graphite. There was found that graphite occurred earlier (approx. after one hour) in the case of the modified cast iron compared to the unmodified cast iron (approx. after two hours).

There was observed that the cast iron modification resulted in cementite decomposition the longer the holding time was.

In terms of the mechanical stresses applied, they were exceeded:

- there was obtained a graphitization process in a white structure cast iron in two stages, differing in principle;

- in the first stage, the aim was to partially achieve the first stage of the graphitization by liquid cast iron inoculation;

- the studies performed on the samples obtained showed that graphite particles formed in the white cast iron mass on the background of a hypoeutectic structure (pearlite and eutectic with cementite);

- the shape of the graphite separations, fine in size and uniformly distributed in the metal mass, is almost globular;

- following a heat treatment in solid state applied to the same samples, the second stage of graphitization was triggered; this consisted in the decomposition of the eutectic with cementite and partially of the eutectoid pearlite; as a result of these processes, the secondary graphite was deposited on the existing graphite particles, and there increase in volume was observed;

- the graphite thus formed has a compact shape, almost spherical; 
- by successive application of these technologies, a cast iron with compact graphite was obtained, after a total duration of the processes of only $1 . . .4$ hours;

- we consider that the liquid cast iron inoculation with a very small amount of modifier, as a secondary result, leads to the stimulation of the processes of decomposition of primary and secondary cementite and, as a result of this effect, the significant shortening of the malleableizing process.

\section{References}

1. Miloșan I. (2011): Elaborarea și turnarea fontelor cu grafit nodular (Elaboration and casting of nodular graphite cast irons). Editura Universității Transilvania, ISBN 978-973-598-859-3, Brașov, Romania (in Romanian)

2. Rădulescu M. (1982): Studiul materialelor metalice (Study of metallic materials). Editura Didactică și Pedagogică, București, Romania (in Romanian)

3. Sofronie L., Riposan N. (1985): Turnarea fontelor (Casting of cast iron). Editura Didactică și Pedagogică, București, Romania (in Romanian)

4. Crișan A., Geamăn V. (1998): Fonta maleabilă (Malleable cast iron). Editura Universității Transilvania, ISBN 973987675, Brașov, Romania (in Romanian)

5. Chakrabarty I. (2019): Characteristic Properties and Development of Microstructures by Heat Treatment of Unalloyed and Low-Alloyed Cast Irons. Materials Science and Materials Engineering, ISBN 978-0-12-803581-8, p. 1265-1279, https://doi.org/10.1016/B978-0-12-803581-8.10091-8

6. Elkabir G., Rosen A. (1981): Effect of microstructure on the fragmentation characteristics of malleable cast iron materials. Materials Science and Engineering, ISSN 0921-5093, Vol. 51, issue 2, p. 265-269, https://doi.org/ 10.1016/0025-5416(81)90203-2

7. Capus J. (2012): A new PM route for machinable, malleable iron. Metal Powder Report, ISSN 0026-0657, Vol. 67, issue 5, p. 30-32, https://doi.org/10.1016/S0026-0657(12)70078-4

8. Kuryło P. (2012): Possibility of Plastic Processing of Spheroidal Cast Iron. Procedia Engineering, ISSN 1877-7058, Vol. 48, p. 326-331, https://doi.org/10.1016/j.proeng.2012.09.521 